\title{
A Perspective on the "Spontaneous" Cures Associated With the Sacred
}

\author{
Paulo Nuno Martins* \\ Transdisciplinary Center for Consciousness Studies, CTEC, University Fernando Pessoa of Oporto, \\ Portugal, \\ Interuniversity Center for History of Science and Technology, CIUHCT, New University of Lisbon, \\ Portugal,
}

\begin{abstract}
*Corresponding Author: Paulo Nuno Martins, Transdisciplinary Center for Consciousness Studies, CTEC, University Fernando Pessoa of Oporto, Portugal, \& Interuniversity Center for History of Science and Technology, CIUHCT, New University of Lisbon, Portugal,
\end{abstract}

\begin{abstract}
In this article, the theme of "spontaneous" cures associated with the Sacred, which have occurred over time in various parts of the world, is addressed. However, conventional medicine has not found a scientific explanation for these occurrences, according to current medical knowledge. Thus, through the intersection of Transpersonal Psychology, Quantum Mechanics and Eastern Medicine (Ayurveda), I intend to give a personal perspective on the occurrence of such facts, namely with a practical application to a case study that occurred with Bernadette Moriau, in the Sanctuary of Lourdes.
\end{abstract}

Key words: Case report on Bernadette Moriau, "Spontaneous" cures associated with the Sacred, Integrative medicine.

\section{INTRODUCTION}

This article on the relationship between "spontaneous" cures and the Sacred is intended to refer to "spontaneous" cures or miraculous healings that different pilgrims have described when they go to the various Sanctuaries scattered across the globe [1]. In the case of the Marian Apparitions in Lourdes, which occurred with the "seer" Bernardette, in the $19^{\text {th }}$ century, there have been deep investigations in the theological [2] and medical [3] fields into some "anomalous phenomena", particularly the "spontaneous" cures that have occurred in the grotto and the swimming pools of the Sanctuary of Lourdes.

In historical terms [4], these "spontaneous" cures have aroused great debatesince the 19th century. While, scientific positivism has sought to devalue the "miraculous" cures (attributing them an illusory character), the Catholic faith has seen these "miraculous" cures as a sign of the Divine in the world. These two different perspectives have used various political and social influences to defend their positions.

In this regard, it should be mentioned that in the 18th century, Pope Benedict XIV published an Encyclical entitled "De servorum beatificatione et beatorum canonizatione" ("the beatification of the God's servants and the canonization of the Blessed") which sought to establish some criteria for the identification and recognition of "extraordinary events" within the religious scope, such as "miraculous" cures, clairvoyance, etc. Thus, in 1858, the International Medical Commission was created by Cardinal Laurence to «verify the authenticity and nature of the events that had taken place in Lourdes» [5]. Furthermore, in 1883, the "Bureau des Constatations Médicales" (BCM) was created in Lourdes and has been constituted mostly by physicians who sought to scientifically describe the "spontaneous" cures, as an "anomaly" in the biological laws of Nature.So, physicianshave prepared several dossiers with clinical examinations of the patient's conditions, before and after the patient's visit to the Sanctuary of Lourdes, emphasizing the respective Grace received by the pilgrim.It should be noted that the medical-scientific methodology applied to validate (or not) these "spontaneous" cures has met the seven criteria that were defined by the Cardinal Prospero Lambertini, in the 18th century. These criteria are as follows:a) The diagnosis should be based on medical knowledge; b) The 
disease should have a negative prognosis by conventional medicine; c) The disease should be exclusively organic; $\mathrm{d}$ ) For each type of disease, the treatment indicated by conventional medicine should not favor the cure; e) The cure should be sudden, unexpected and instantaneous; f) The cure should be without convalescence; g) The cure should be lasting[6].

Thus, of more than a total of 7200 "spontaneous" cures submitted to BCM, only 70 have been validated using the seven criteria mentioned above. Subsequently, the Church has prepared a Report to describe the "miraculous" essence of these "spontaneous" cures from a theological point of view [7]. Of the 70 cases validated by specialists in these areas of knowledge, some examples should be mentioned..The first case was that of Catherine Latapie who was pregnant and had an ulnar paralysis on her right arm. During the Marian Apparitions that have taken place in Lourdes, she placed her hand in a cave wall of Massabielle. Her hand was healed, and she gave birth to a baby when she returned home.

In 1965, a"spontaneous" cure also occurred with the religious LuiginaTraverso who was suddenly cured of a crippling sciatica, during the exposition of the Blessed Sacrament in the celebration of the Eucharist, after previously undergoing several surgeries and medical treatments without success.

Sister Luigina saidthat she «felt a feeling of a strong warmth and well-being while at the same time being able to stand easily». However, it was only in 2012, that this "miracle" was recognized by the Church (Vatican).

Finally, in 1989, Danila Castelli was also cured "spontaneously" in the Sanctuary of Lourdes but validation for this cure implied 24 years of studies and research by the scientific community and BCM [8]. There are many other cases of "spontaneous" healing that occurred in the Sanctuary of Lourdes that are described in the specific literature on this topic [9].

\section{BernadetTe Moriau'S "Spontaneous" Cure in the Sanctuary of Lourdes: A CaSe REPORT.}

In this article, I will be described a Case Report (a summary) about a nun named Bernadette Monriau, who was cured "spontaneously" at the Sanctuary of Lourdesas reported by the journalist Rosa Ruela [10]. In historical terms, this nun was the eldest daughter of a humble large family from Rennes in the North of France, having entered into the Oblate Franciscan Congregation of the Sacred Heart of Jesus at the age of 19. Five years later, she began to suffer from an unbearable pain in her back. In medical terms, this woman had the so-called "ponytail" which is a neurological condition that causes the compression of the root of the spinal nerves. So, shedid four surgeries (1968-1975), but without success. In 1988, she was declared invalid (wore a hard bodice), and 6 years later, shebegun to take morphine for the pains to be able to walk. In 2004, all day long, she started to use an iron splint because her feet were turned over. In July 2008, she said that she decided to go to the Sanctuary of Lourdes (southern France), accompanied by a group of patients, and according to her description "In the Basilica of Lourdes, she felt the presence of Jesus in the blessing of the sick. This same presence of Jesus was again felt in the chapel of the convent where she lives currently. In fact, it was 17:40, and she felt a well-being throughout the body, accompanied by relaxation and warmth. When she returned to the room, she heard a voice that said to her: "Take away the apparatuses". Bernadette said that she followed the voice, realizing that she was able to move without needing any apparatus, with the feet (which were turned) now straightened. In addition, she stopped with the neuro-stimulator and morphine because her pains had disappeared».This event was attested by the Italian physician Alessandro de Franciscis who confirmed the 70th "spontaneous" cure atthe Sanctuary of Lourdes.

\section{The EXPERIMENT OF NON-LOCALITY IN QUANTUM PHySiCs: An OVERVIEW}

There are some scientific experiments that allow us to conjecture an explanation for the occurrence of "spontaneous cures", namely the experience of Alain Aspect and collaborators. The physicist Alain Aspect and his collaborators [11] have verified quantum non-locality, i.e., the possibility of two quantum correlated objects - for example two photons - communicate instantly and independently, regardless of their distance.

This experiment followed a conceptual experiment proposed by Einstein, Podolsky and Rosen, a few years earlier [12]. In the experiment performed by Aspect and his collaborators, the two photons correlated by polarization, coming from the same source, and moving in opposite directions. Each photon could be described by an overlap of "quantum waves of possibilities". When a measurement 
of one of the photons occurs (referred to as "collapse of the wave function"), the other correlated photon "collapse" simultaneously into identical states of polarization, although there has been no exchange of signals in space-time to be in accordance with the Theories of Relativity that predicts the exchange of information (in space-time) at the speed of light. Furthermore, It should be stated that the "collapse of the wave function" of a set of "possibilities" only occurs when there is a conscious choice made by the subject. The measurement is considered complete only when the subject manifests in the concrete world, the choice made previously.Furthermore, it should be said that if the quantum particles are"unrelated" or "not intricate" between them, they behave independently and separately, and so "the collapse of the wave function" or the measurement of one of them does not simultaneously cause the "collapse of the wave function" of the other quantum particle.

In this regard, Jacobo Grinberg-Zylberbaum [13] and his colleagues performed the Aspect nonlocality experiment between the brains of two shamans [14]. These two shamans were correlated through joint meditationto establish a direct communication. After this procedure, the two shamans were separated and placed in electromagnetically isolated cameras and connected to different electroencephalogram (EEG) machines. When one of them saw a series of flashes of light that produced an"evoked potential" in the EEG, an equal "transferred potential" (in phase and intensity) appeared in the EEG of the other shaman. However, the volunteers in the control group did not demonstrate any kind of "transferred potential" between them. That happens because there is no "intricacy" between the elements of the control group, so they behave as separate entities. In fact, "intricacy" only occurs when there is a "conscious intention" between the two entities for this to occur. The conclusion is that a correlation of similar "possibilities"and an instantaneous "collapse" through non-local consciousness occurred between the two shamans'brains separated at a given distance [15].

\section{A Perspective on the "Spontaneous" Cures Associated With the SaCred: An Essay}

In line with the researcher's perspective a possible explanation for the "spontaneous" healings associated with the Sacred could be found in the interpretation of Egg's Diagram of Assagioli[ 16]. In this diagram, it is represented the unconscious side of the human being, the field of consciousness or perception, the conscious self or "I", the Soul or the Real Self, and, the connection between the Soul and the "I" are represented [17]. In the field of consciousness mind, it appears the "mental and emotional patterns"- designated by "Archetypes" [18]- that could be described as "quantum waves of possibility" which might have a causal effect on patient's health [19].

Furthermore, the "spontaneous" cures might occur due to an "intricacy" or non-local connection between the patient's soul (Bernadette) and the Divine entity (Jesus). Thus, the subject needs to make the decision or choice to connect to the Divine, so that the "collapse of the quantum waves of possibilities" might occur between them [20]. This situation is described by Bernadette: «In July 2008, I decided to go to the Sanctuary of Lourdes (southern France), accompanied by a group of patients, and "in the Basilica of Lourdes, I felt the presence of Jesus in the blessing of the sick"》. Furthermore, it is also referred to in the case study: "When she returned to the room, she heard a voice that said to her: "Take away the apparatuses". Bernardette followed the voice, realizing that she was able to move without the need of any apparatus, with the feet which were turned now straightened. In addition, she stopped with the neuro-stimulator and morphine because her pains had disappeared». This "instant communication and healing" is also referred to in the sacred texts of the various Religions. For example, in the Bible [21] the evangelists said that «Jesus healed (instantly) a sick manin the pool of Bethesda... the servant of the centurion ... the blind man from Jericho because they had faith in Jesus, etc». So, from the researcher's point of view, the patient's faith in Jesus is a "possible way" to establish the"quantum intricacy" necessary for the miracle to take place in reality. In fact, we could read in the Bible that in most of the curesper formed by Jesus, He said at the end of the healing process: «Go in peace, your faith has healed you» or ««Go and do not sin again». In this regard, It is referred that sometimes physical healing might involve a process of changing personal values [22].

Indeed, one aspect of "spontaneous" cures might be connected to the non-locality of the Aspect's experiment and what Carl Jung called Synchronicity - a "significant coincidence" of events that are connected not by a causal relationship but rather by a relationship of meaning that lies between the mind of the healer and the mind of the sick"'[23]. In the literature on instant cures, the phenomenon of synchronicity and non-locality is presented in several ways, as reported by O'Regan [24] and Byrd 
[25], where distant prayers and meditation might be another way for the "intricacy" process to take place and so lead to the recovery of patient's health. This "quantum intrincacy" might be justified by a deeper interdependence where everything is interconnected [26]. In this regard, It should be noted that this type of "inexplicable" cures might mean that there are several "levels of Consciousness" (as defended by Eastern thought) or "levels of Reality"(as defended by Western thought) through which the healing process is carried out from a level of unmanifestedreality to another level of manifested reality through the "Logic of the Included Third" [27].

Another aspect of "spontaneous" cures might also be related to the results of the Aspect's experiment of "instantly, lasting and inexplicable" communication between two correlated photons (similar to the experiment performed by Grinberg-Zylberbaum, referred to earlier). It is because of this that some physicians named these cures as quantum healings [28]. In fact, this situation is referred by the Italian physician Alessandro de Franciscis: «Our method of research work is very strict, and there is no room for the decoy»". Since 2009, this physician has studied this process"of instant, lasting and inexplicable healing, according to current scientific knowledge", and so, in February 2018, he declared the 70th "spontaneous" cure that occurred in the Shrine of Lourdes.

In this regard, It is important to mention that some of these "spontaneous" cures are similar to some Near-Death Experiences which are described in the specialized literature on this topic [29].In fact, It should be noted that the physician Patrick Theillier[30] who has worked at the "BCM" of Lourdes has also claimed that many "miracles" that have occurred in the Sanctuary of Lourdes are similar to some Near-Death Experiences.

In the Sanctuary of Lourdes, Patrick Theillier witnessed some "unexplained occurrences from the scientific point of view" that are similar to some patients who have undergone Near-Death Experiences -cardiac arrest and no brain activity for a short period- and then the patient came back to life.

For this purpose, It is important to note thata common characteristic of "spontaneous" cures where the patient feels warm and well, as described by Bernadette: "In fact, it was 17:40, and I felt a well-being throughout the body, accompanied by relaxation and warmth». In this regard, I would like to mention the "awakening" of yogis' kundalini which is accompanied by a warming up of the body and a change in the subject's self-consciousness [31].

On the other hand, It is important to mention that there are a large number of patients who went to Marian Shrinesto beg God for a cure for their "incurable diseases", even though the patients ended updying from these diseases[32].From the researcher's point of view, the "non-intricacy" between the patient and the Divine and the non-occurrence of a "spontaneous" cure in these several cases might be due to "karmic" factors where it is not possible to change the patient's situation (it has nothing to do with punishment or judgment)[33].

\section{CONCLUSiON}

This case report that occurred between Bernadette Moriau (patient) and Jesus (the Sacred) is similar to other"spontaneous" cures described by pilgrims in other Shrines [34] and call into question two topics that appear in the history of medicine [35]: The incompleteness of the Cartesian model(dualistic and mechanistic) that treats the patient's body as a "machine" through the exclusive use of allopathic medicines (with side effects) [36] and the need to find anintegrative medicine model that might address the various dimensions of the patient (physical/biological, psychological and spiritual), during the healing process [37]. Several integrative medicine models maintain that the mind affects thepatient's physical health [38]. This new approach to medical practice might contribute to find a "scientific" explanation for the occurrence of "spontaneous" cures, such as that which occurred with Bernadette Moriau [39], and thus see medicine and spirituality as complementary in the cure of the patient [40].

\section{REFERENCES}

[1] Laurentin, R.(1990). The Apparitions of the Blessed Virgin Mary Today.Ignatius Pr.

[2] Laurentin, P. (1998). Bernadette of Lourdes.Darton, Longman \&Todd. 
[3] Vallet, A. (1929). Mesconférencessurlesguérisons de Lourdes. P. Téqui\&Fils.

[4] Sales, L. (2016). As curas milagrosas da Virgem Maria em Lourdes: a controvérsia médico-religiosa. Anuário Antropológico I, 153-172.

[5] Walsh, J. (2014). Our Lady of Lourdes.Coll. Christi Regis.

[6] Holland, T. (2016). Os 7 critérios científicos de uma cura milagrosa. Aleteia Brasil.

[7] Bernardo, A. (1992). Lourdes-The Comprehensive Text.Andre Doucet Publication.

[8] Mangiapan, T. (1997). Lourdes-Miraculous Cures. Printing Press of the Gotto.

[9] Segur, Mgr and TOSF, B.H. (2014). The Wonders of Lourdes. Create Space Independent Publishing Plataform.

[10] Ruela, R. (2018). Recuperação de freira terá sido o $70^{\circ}$ milagre de Lourdes (e usamos o futuro porque temos dúvidas sobre o que se passou realmente), Revista Visão, February 2018.

[11] Aspect, A. and Dalibard, J. and Roger, G. (1982). Experimental test of Bell inequalities using time-varying analyzers.Physical Review Letters 49:1804-1806.

[12] Einstein, A. and Podolsky, B. and Rosen, N. (1935). Can Quantum Mechanical description of Physical Reality be considered completed?, Physical Review 47, 777.

[13] Grinberg-Zylberbaum, J. and Delaflor, M. and Attie, L. and Goswami, A. (1994). Einstein-PodolskyRosen paradox in the Human Brain: The Transferred Potential. Physics Essays, 7(4): 422-428.

[14] Martins, P. (2009). A Mecânica Quântica e o pensamento de Amit Goswami. Tese de Doutoramento, Faculdade de Ciências e Tecnologia da Universidade Nova de Lisboa. Pages 302-304.

[15] Goswami, A. (2012). The Visionary Window.Quest Books.

[16] Assagioli, R. (1976). Psychosynthesis: A Manual of Principles and Techniques. Penguim.

[17] Miller, S. (1973). The Rebirth of the soul, interview with Roberto Assagioli, Intellectual Digest, August 1973.

[18] Jung, C. (1968). Analytical Psychology: Its Theory and Practice. Vintage Books.

[19] Ponte, D. et al. (2013). Carl G. Jung, Quantum Physics and Spiritual Mind.Behav. Sci. 3(4):601-618.

[20] Goswami, A. (2004). The Quantum Doctor.Hampton Roads Publishing Co.

[21] Costa, A. et al. (1981). Bíblia Sagrada. Difusora Bíblica.

[22] Martins, P. (2020) Fatima and the values of contemporary society: An essay. Icon of Faith, International Journal of Interdisciplinary Scientific Research, 11(6):37-40.

[23] Jung, C. (1960). The Structure and Dynamics of the Psyche.Princeton University Press.Collected Works, Vol.8.

[24] O’Regan, B. (1987). Spontaneous Remission: Studies of Self-Healing Institute of Noetic Sciences.

[25] Byrd, C. (1988). Positive therapeutic effects of intercessor prayer in a coronary care unit population.Southern Medical Journal 81(7): 826-829.

[26] Capra, F. (1996). The web of Life.Simon and Schuster.

[27] Nicolecu, B. (2015). Nous, la particuleetle monde. EME Éditions.

[28] Chopra, D. (1989). Quantum Healing.BantamBooks.

[29] Martins, P. (2019) Ciência e a Teoria da "Vida após a Morte": Algumas considerações sobre a filosofia da ética. Consciências 6:67-80. Download fromhttp://ctec.ufp.pt/wpcontent/uploads/2019/04/ConsCi\%C3\%AAncias_6-1.pdf.

[30] Theillier, P. (2017). Near-Death Experiences Examined: medical Findings and Testimonies from Lourdes. The Crossroad Publishing Company.

[31] Jung, C. (1999). The Psychology of Kundalini Yoga.Princeton University Press.

[32] Dufaur, L. (2009). Lourdes e Suas Aparições: Esperança para Quem Precisa de Socorro. Editora Petrus.

[33] Iyengar, B. (2008). Light on the Yoga Sutras of Patanjali.EditoraThorsons.

[34] Watkins, C. (2011). Full of Grace.Ave Maria Press.

[35] Porter, R. (1999). The Greatest Benefit to Mankind.W.W.Norton\&Company.

[36] Martins, P. (2018). Descartes and the paradigm of Western medicine: An essay. International Journal of Recent Advances in Science and Technology, 5(3):32-34.

[37] Martins, P. (2018). Being Transdisciplinary in Human Sciences: The usefulness of Integrative medicine in contemporary society.Transdisciplinary Journal of Engineering and Science, 9(5): 37-43.

[38] Wolf, F. (1986). The Body Quantum.Palgrave Macmillan. 
[39] Weil, A. (1995). Spontaneous Healing.Alfred Knopf.

[40] Martins, P. (2020). História da Ciência, Psicologia Junguiana e Espiritualidade: uma visão transdisciplinar para a qualidade de vida", Religião, Espiritualidade e Qualidade de Vida, In: J. Brissos-Lino, B. Gonzalez (Org.), Edições Universitárias Lusófonas, 2: 59-65. 2020.

\section{AUTHOR'S BIOGRAPHY}

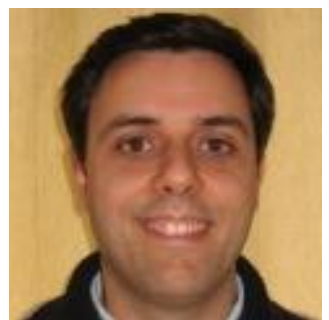

Paulo Nuno Martins, is a Chemical Engineer with a specialization in Biotechnology (Instituto Superior Técnico, University of Lisbon) and a $\mathrm{PhD}$ in History and Philosophy of Science (Faculty of Sciences and Technology, New University of Lisbon). He studied for 4 years Oriental languages and culture (Hindi, Chinese, Japanese) and he is currently a researcher in CIUHCT, New University of Lisbon, Portugal and CTEC, University Fernando Pessoa of Oporto, Portugal (http://orcid.org/0000-0002-2670-3172). He is a member of CIRET (Centre International de Recherchesetd 'Études Transdisciplinaires), Paris.

Citation: Paulo Nuno Martins. "A Perspective on the "Spontaneous" Cures Associated With the Sacred" International Journal of Humanities Social Sciences and Education (IJHSSE), vol 7, no. 5, 2020, pp. 35-40. doi: http://dx.doi.org/10.20431/2349-0381.0705004.

Copyright: (C) 2020 Authors. This is an open-access article distributed under the terms of the Creative Commons Attribution License, which permits unrestricted use, distribution, and reproduction in any medium, provided the original author and source are credited. 